\title{
RUBIES AND SAPPHIRES FROM SNEZHNOE, TAJIKISTAN
}

Elena S. Sorokina, Andrey K. Litvinenko, Wolfgang Hofmeister, Tobias Häger, Dorrit E. Jacob, and Zamoniddin Z. Nasriddinov

Discovered during the late 1970s, the Snezhnoe ruby and sapphire deposit in Tajikistan was active until the collapse of the former Soviet Union in the early 1990s and the outbreak of regional conflicts. This marble-hosted occurrence has seen renewed interest, as it is a large and potentially productive deposit that has not been sufficiently studied. Testing of samples identified solid inclusions of margarite enriched with $\mathrm{Na}$ and $\mathrm{Li}$ (calcic ephesite or soda margarite). These are believed to be previously unreported for gem corundum. Allanite, muscovite, and fuchsite (chromium-bearing muscovite) were identified for the first time in ruby and sapphire from Snezhnoe. These and other inclusions such as zircon, rutile, Kfeldspar, and Ca-Na-plagioclase could serve to distinguish them from stones mined elsewhere. Concentrations of trace elements were typical for ruby and sapphire of the same formation type. The highest $\mathrm{Cr}$ concentrations were observed within the bright red marble-hosted rubies, and these values were very similar to those of the famous Burmese rubies from Mogok.

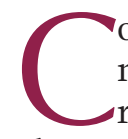
orundum- $\alpha-\mathrm{Al}_{2} \mathrm{O}_{3}$-is a common, though minor, component of many metamorphic rocks. Gem-quality varieties of ruby and sapphire occur in only a few primary metamorphic and magmatic rock types depleted in silica and enriched in alumina (Giuliani et al., 2007) and in the secondary placers formed by the erosion of these rocks (e.g., Hughes, 1997; Kievlenko, 2003).

The traditional supplier of ruby and sapphire to the world markets is Southeast Asia. Burmese rubies from the Mogok deposit have historically held the highest value, stemming from their "pigeon's blood" color, a bright red with a slightly purple hue (Hughes, 1997; Smith, 1998). The supply situation has changed dramatically in recent years, with the discovery of new deposits in East Africa and the continued mining of the Central and Southeast Asian occurrences.

Situated within the Pamir Mountains, Tajikistan produces a variety of gemstones, including ruby (figures 1 and 2), sapphire, spinel, aquamarine, chrysoberyl, tourmaline, topaz, clinohumite, gar-

See end of article for About the Authors and Acknowledgments.

GeMs \& GemOlogr, Vol. 51, No. 2, pp. 160-175,

http://dx.doi.org/10.5741/GEMS.51.2.160.

(C) 2015 Gemological Institute of America net, scapolite, lazurite, and variscite (Litvinenko and Barnov, 2010). The occurrence of ruby in the Pamirs was first suggested by the Soviet mineralo-

Figure 1. The bright red faceted ruby in this gold ring is from the large and potentially productive Snezhnoe deposit in Tajikistan. Photo by Zamoniddin Z. Nasriddinov.

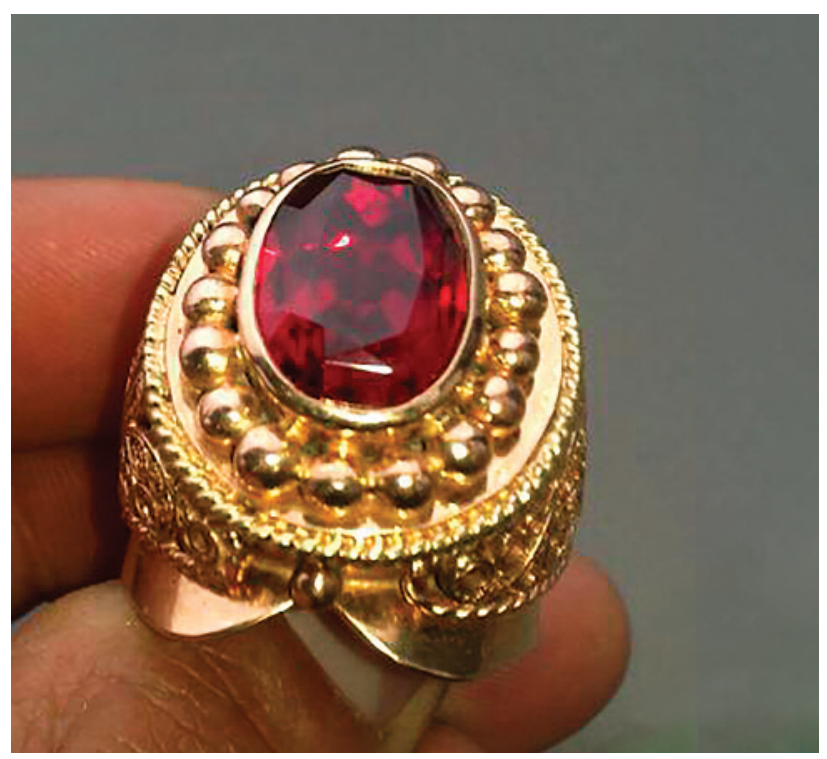




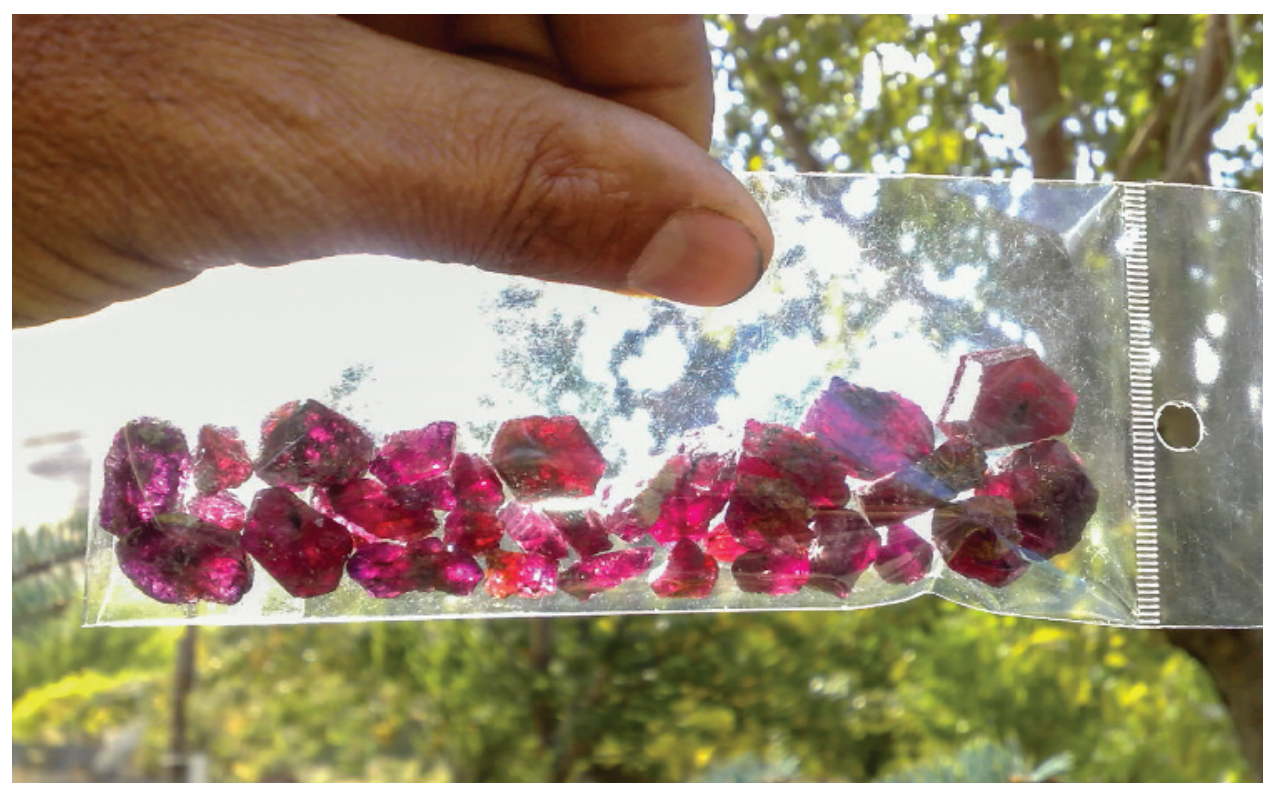

Figure 2. These rough ruby crystals are from the Snezhnoe deposit. Photo by Zamoniddin Z. Nasriddinov.

gist and geochemist A.E. Fersman in the early 1930s (Popov, 1936). Fersman predicted the location of ruby deposits in the Precambrian metamorphic rocks of the southwestern Pamirs, where the geological conditions are similar to those in Myanmar and Sri Lanka. This hypothesis was confirmed by Ya. A. Gurevich, I.M. Derzhavets, and colleagues during a prospecting expedition to the Pamirs in 1965, when they found a group of ruby and sapphire deposits on the western slope of the Ishkashim ridge (Litvinenko and Barnov, 2010).

\section{In Brief}

- The Snezhnoe ruby occurrence in Tajikistan is a large and potentially productive source of gem corundum.

- The highest $\mathrm{Cr}$ concentrations were observed in the bright red marble-hosted ruby, which had a value close to those of similar genetic type, including the famous Burmese rubies from Mogok.

- The study identified previously undocumented solid inclusions that are useful for the origin determination of this gemstone.

Marble-hosted ruby deposits were first detected in the Shakhdarin series (Archean age) in 1979 (Konovalenko and Rossovsky, 1980). The subsequent discovery of a new gem deposit structure-a ruby belt on the eastern part of the Central Pamirs-became something of a sensation in the 1980s (Litvinenko and Barnov, 2010). More than 50 marble-hosted ruby occurrences confined to the gneiss-marble suite of the Muzkol metamorphic complex (Paleoproterozoic) have been found within this zone. The largest of these are Snezhnoe and Trika, discovered in 1980, and Nadezhda, which followed a decade later (Litvinenko and Barnov, 2010). After the collapse of the Soviet Union, all mining and prospecting activity at these deposits was suspended for more than 15 years. Today, production figures are kept confidential by the Tajik government. Regional conflicts, combined with difficult access and climate conditions, have complicated further study of these gem deposits, though a period of stability allowed foreign researchers to visit them in the early 21 st century (Bowersox, 2005; Hughes et al., 2006).

Petrographic, mineralogical, and gemological research has been conducted at various times, both by Soviet and then Russian scientists (Dmitriev, 1983. Dmitriev and Ishan-Sho, 1987; Dufour et al., 2007) and their foreign counterparts (Henn and Bank, 1990, Smith, 1998). For this article, we have updated knowledge about the geology of the Snezhnoe deposit and separated various types of ruby and sapphire crystals according to their morphology, gemological properties (including reflectance and luminescence spectra), trace-element composition, and previously unreported solid inclusions.

\section{REGIONAL GEOLOGY}

The Snezhnoe deposit is confined to the Kukurt anticlinal fold belonging to the south wing of the Shatput anticline (Kievlenko, 2003) within the eastern 

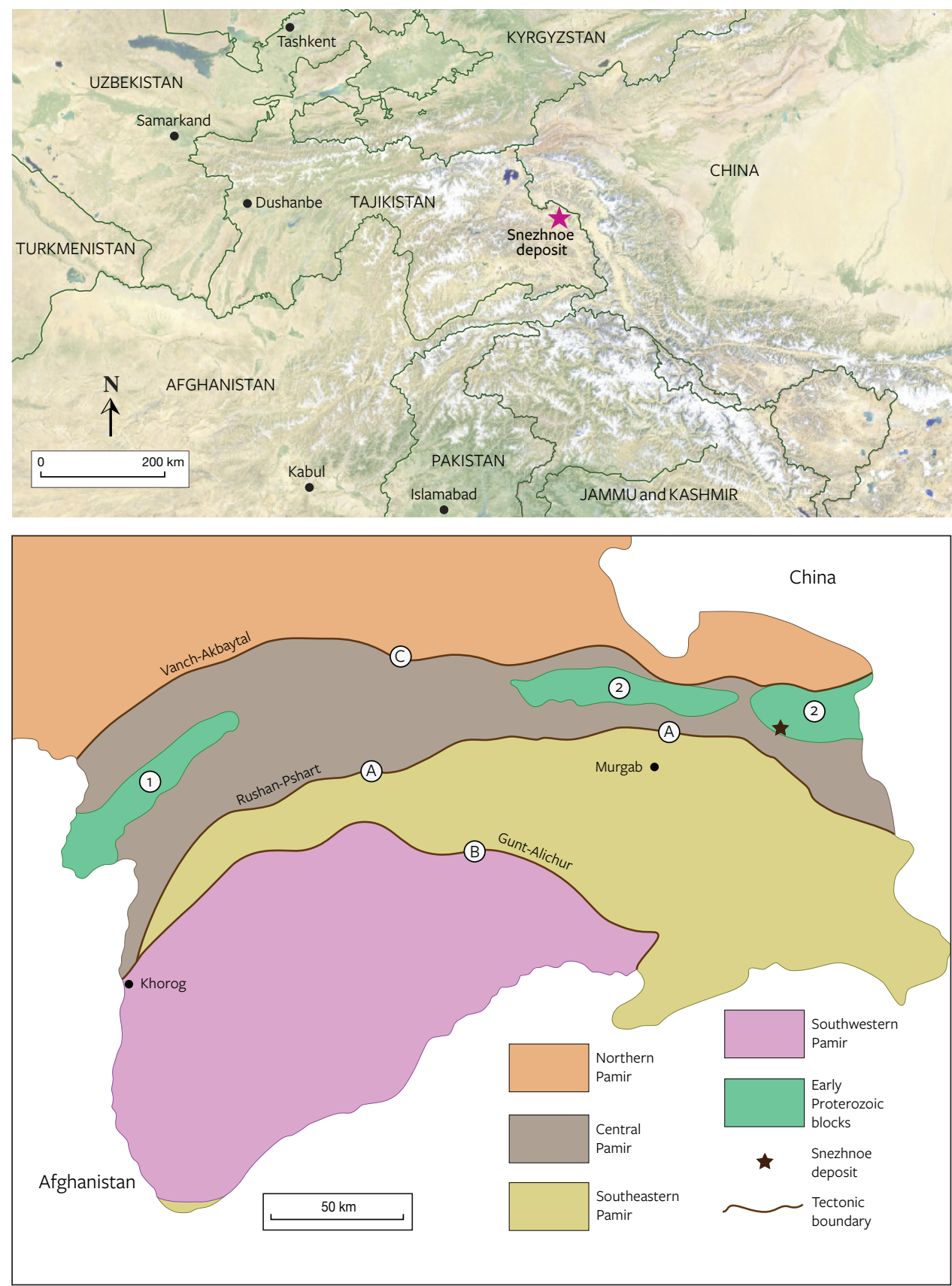

Figure 3. Top: A map of the Snezhnoe marblehosted ruby deposit within Central Asia. Bottom: A regional geological map of the Pamir Mountains of Tajikistan and the location of the Snezhnoe deposit. The northern, central, southeastern, and southwestern Pamirs are folded regions around early Proterozoic blocks, one of which includes the Snezhnoe deposit. The northern Pamir is related to the Hercynides, whereas the central, southeastern, and southwestern Pamir represent Cimmerian Plate remnants. There are deep faults or tectonic boundaries between these regions. The circled A represents the Rushan-Pshart deep fault, while the circled $B$ indicates the GuntAlichur deep fault. The circled $C$ represents the Vanch-Akbaytal deep fault. The circled 1 indicates the VanchYazgulem anticlinorium (an anticlinal structure of regional extent), the circled 2 the MuzkolRangkul anticlinorium. The distance between Khorog and Murgab is $255 \mathrm{~km}$. Modified from Barkhatov (1963). part of the Muzkol-Rangkul anticlinorium (outcrop of the Precambrian crystalline basement by Rossovsky, 1987; figure 3). The core of the Kukurt fold is characterized by the development of granitegneiss in the Zarbuluk complex (possibly Proterozoic, age not determined) surrounded by gneisses and schist (Belautin suite), calcite and dolomite marbles (Sarydzhilgin suite), and quartzites and quartz sandstones (Buruluk suite) of the Muzkol metamorphic complex (Paleoproterozoic). A massif composed of leucocratic granites from the Shatpur intrusive com- plex (Cretaceous-Paleogene) is adjacent to the eastern part of the fold. The southern part of the fold is cut by the Muzkol regional fault, separating the Precambrian formations from Paleozoic-Mesozoic sedimentary rocks (figure 4).

The ruby-hosted Sarydzhilgin suite, along with other suites of the Muzkol metamorphic complex (total thickness exceeding $6 \mathrm{~km}$ ), underwent at least two tectonic metamorphic cycles. The first took place 1.8-1.6 billion years ago (Budanova, 1991) at amphibolite facies (temperature and pressure approx- 

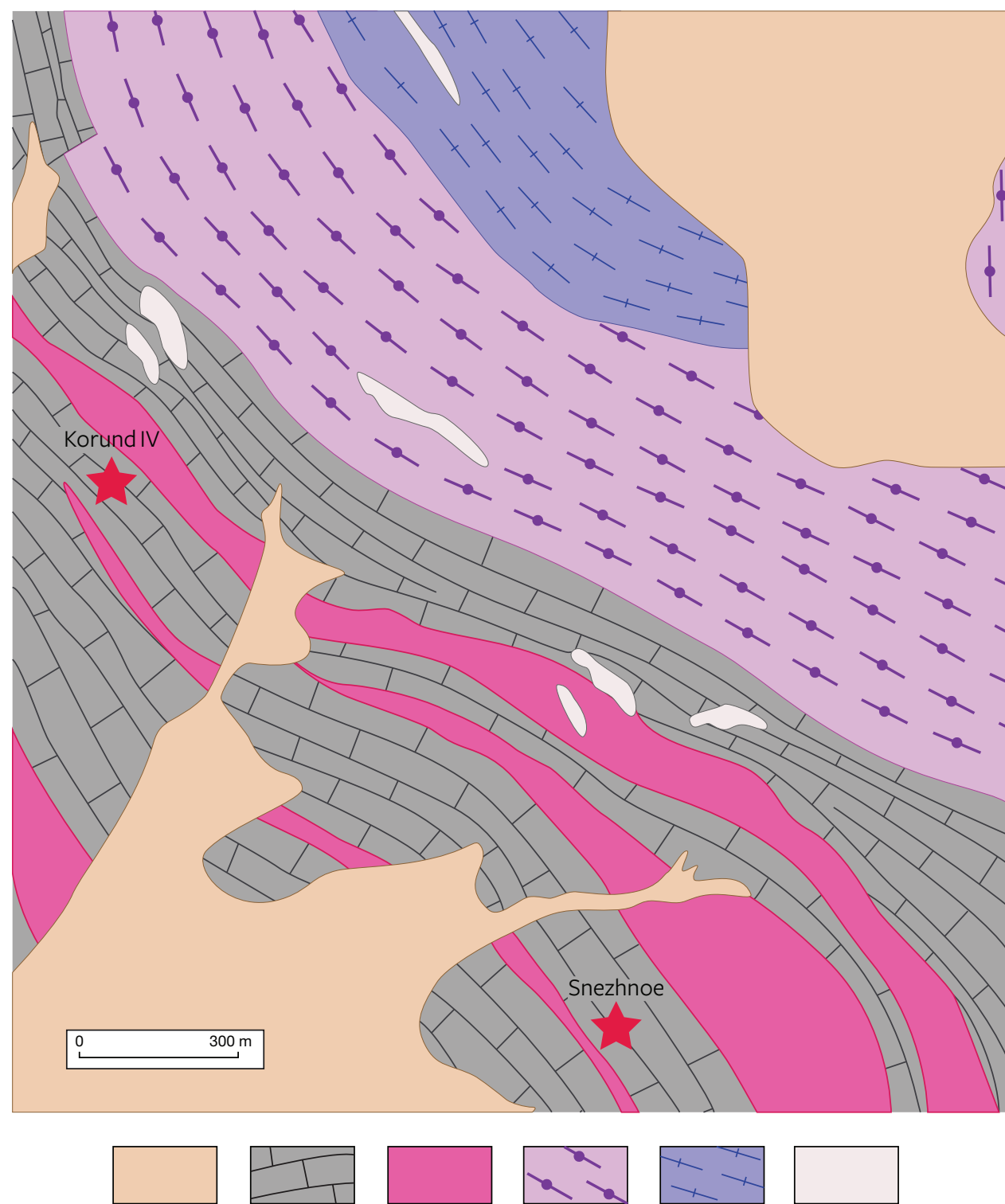

1

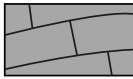

2

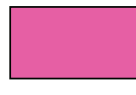

3

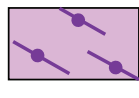

4

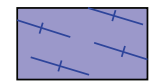

5
Figure 4. This map illustrates the regional geology of the Snezhnoe deposit. 1-sedimentary rocks; Sarydzhilgin suite: 2-marbles; 3kyanite-garnet-biotite, feldspar-biotite, and biotite schists; Belautin suite: 4-garnet gneisses and 5-garnetbiotite gneisses; 6-leucocratic granites of the Shatput intrusive complex. Stars indicate the location of gem corundum deposits. Modified from Kievlenko (2003). imately $700^{\circ} \mathrm{C}$ and $\left.8 \mathrm{kbar}\right)$, and the second cycle occurred 100-20 million years ago (Budanova, 1993). This is a zonal metamorphism migrating from greenschist facies at $350^{\circ} \mathrm{C}$ and $4 \mathrm{kbar}$ through epidote-amphibolite facies up to $800^{\circ} \mathrm{C}$ and $9 \mathrm{kbar}$ (complete melting zone) (Sorokina et al., 2014). There are several theories concerning the geological age of ruby and sapphire crystals in marble, and some researchers believe that formation took place during modern alpine regional metamorphism (Dmitriev and Ishan-Sho, 1987; Dufour et al., 2007).

\section{LOCAL GEOLOGY AND MINERAL ASSEMBLAGE}

The Snezhnoe deposit is located in the eastern part of the Pamir Mountains in Tajikistan. The occurrence is situated $30 \mathrm{~km}$ northeast of Murgab and about $20 \mathrm{~km}$ south of Rangkul, a pair of villages near the Chinese border. It is on the eastern bank of the Aksu River, at an altitude more than 4,000 meters above sea level. The region containing the corundum deposits lies along the Kukurt pegmatite belt, which is enriched with gem scapolite. Ruby and pink sapphire have been found in the formation of coarse- 


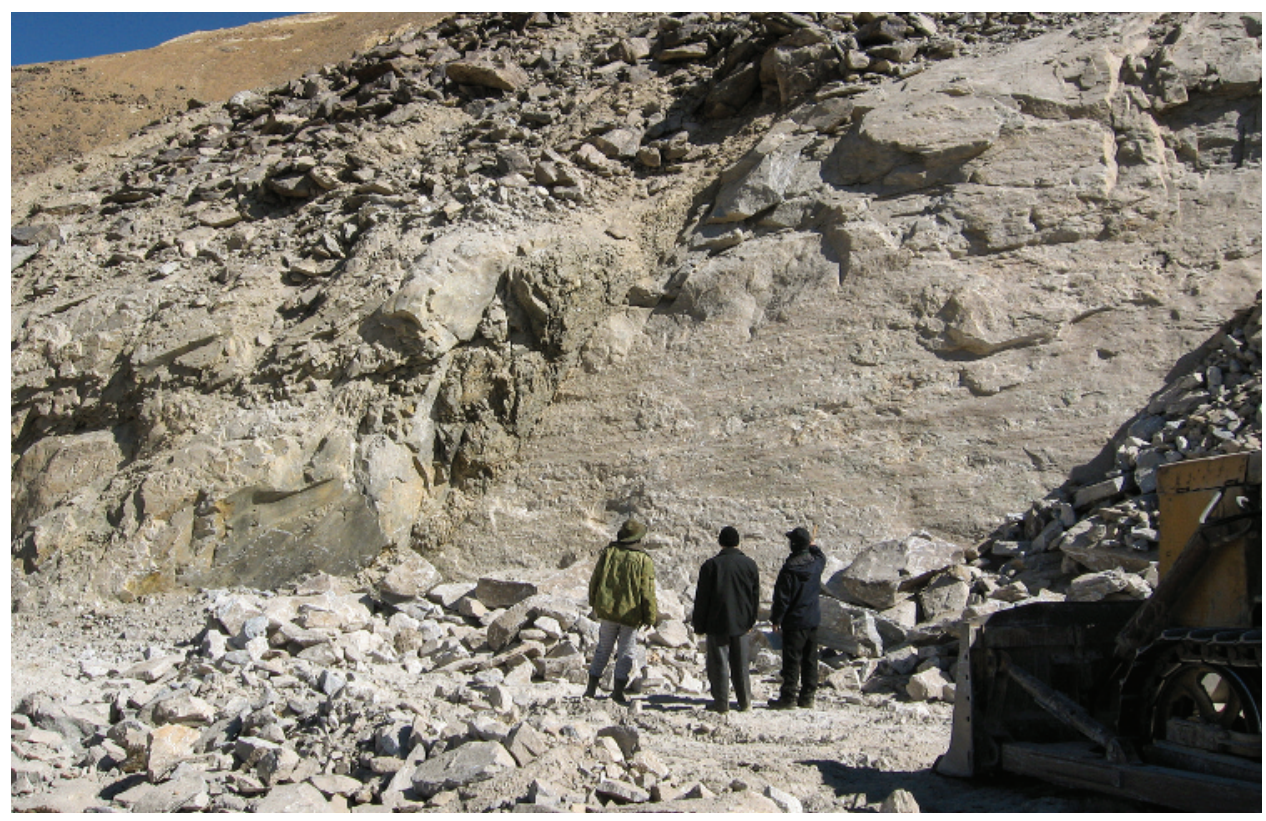

Figure 5. An outcrop of white marbles and dumps at the Snezhnoe deposit. Photo by Andrey K. Litvinenko.

grained calcite marbles from the Sarydzhilgin suite of the Muzkol metamorphic series (Paleoproterozoic), with a total thickness of about $20 \mathrm{~m}$ (figure 5). This formation lies between layers of kyanite-garnetbiotite schist and marbles.

Two ruby-mineralized zones are arranged en echelon (in closely spaced, parallel, or subparallel steplike planes) in coarse-grained calcite marble parallel to their bedding planes. They can be traced along the strike for 150 to $200 \mathrm{~m}$. The mineralized zones are represented by micaceous lenses $(2-15 \mathrm{~m}$ in length, with maximum thickness of $1 \mathrm{~m}$ ) and ruby-bearing marbles contacting with these lenses (figure 6).

Minerals found in micaceous lenses in Snezhnoe include various types of mica (fuchsite and phlogopite), plagioclase (from albite to anorthite), and scapolite (40-

Figure 6. A cross-section of the Snezhnoe marble-hosted ruby deposit illustrates: (1) white marble, (2) graphite, (3) mica, (4) scapolite and plagioclase, (5) ruby, and (6) the main bedding surface controlling ruby mineralization. Modified from Nasriddinov (2013).

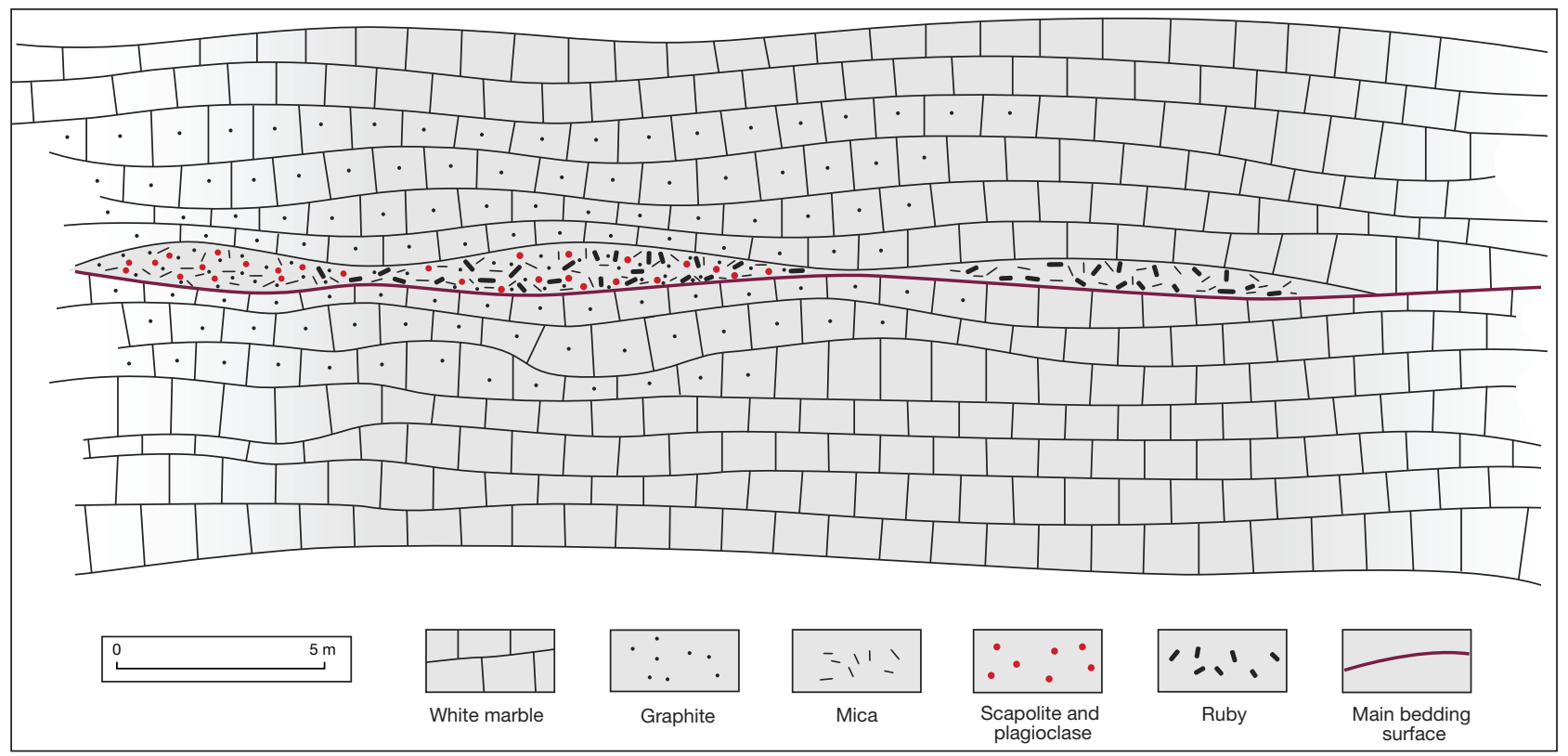




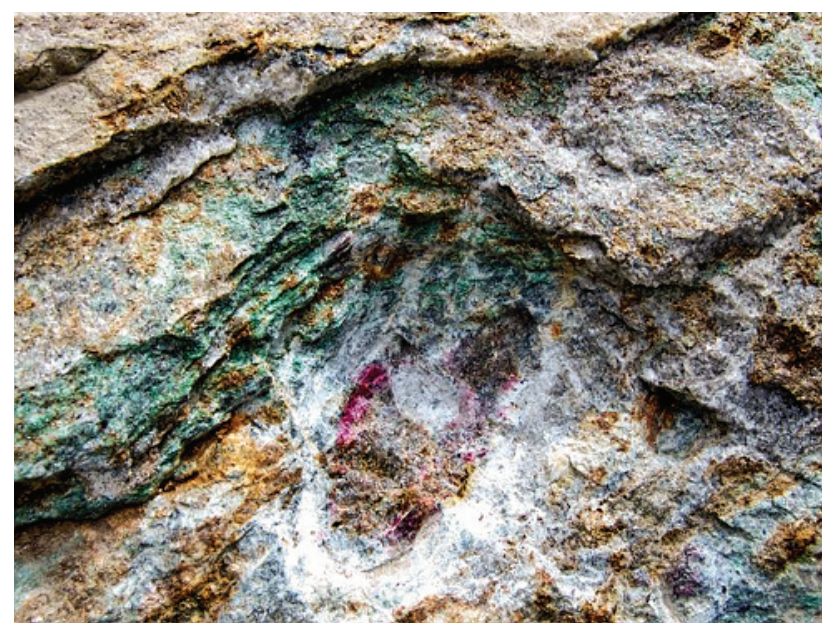

Figure 7. This outcrop of ruby-bearing micaceous lenses within marble has a total thickness of $15 \mathrm{~cm}$. Red ruby crystal can be seen in the center of the photo, surrounded by green fuchsite. Photo by Zamoniddin Z. Nasriddinov.

$60 \%$ meionite), as well as ruby and sapphire, rutile, goethite, carbonates (calcite and dolomite), minerals of the chlorite group, graphite, K-feldspar, and kaolinite (Sorokina, 2011; Sorokina et al., 2012; figure 7). Furthermore, there are marbles that consist mainly of calcite (up to $90 \%$ ), ruby, mica (phlogopite and fuchsite), goethite, scapolite (about 60\% meionite), plagioclase (albite to oligoclase), and graphite. Other researchers have reported amphibole (Rossovsky, 1987), pyrite, and dravite (Kievlenko, 2003).

Soviet-era estimates of the Snezhnoe deposit indicated possible reserves of many hundred thousand carats of gem corundum. The authors of the present article visited the occurrence in 1982, 1986, 2008, 2009,2012 , and 2013. It is currently being worked to a depth of $30 \mathrm{~m}$ by the state-run Chamast enterprise, which is conducting underground mining with drilling tools and large trucks.

\section{MATERIALS AND METHODS}

The authors borrowed 41 ruby-bearing rock samples from Snezhnoe from the collection of the Fedorovsky All-Russian Research Institute of Mineral Resources (FGUP VIMS), which obtained them in the early 1980s. Two additional samples of ruby in marble from this deposit were loaned by the Vernadsky Geological Museum of Russian Academy of Science, courtesy of former chief curator Dr. Mikhail N. Kandinov.

To prepare the sample wafers, the authors cut a section of rock containing ruby and sapphire crystals. The surrounding matrix was either dissolved by $10 \%$ $\mathrm{HCl}$ acid or mechanically removed, or a combination of the two. Standard gemological properties were recorded, including hydrostatic SG, color, and refractive index. We performed long-wave $(365 \mathrm{~nm})$ and short-wave $(254 \mathrm{~nm})$ photoluminescence spectroscopy and observed microscopic features using an MBS-10 binocular microscope. To obtain reflectance spectra in the visible range (380-800 nm), we used a LeicaLeitz MPV-SP spectrometer with a reflection probe and a resolution of $1 \mathrm{~nm}$ and an integration time of $500 \mathrm{~ms}$. Photoluminescence spectroscopy was performed at FGUP VIMS using a MSFU-K (LOMO) microspectrophotometer with an LGI-505 nitrogen laser (337.1 nm wavelength emission), a CAMAC registration system, an IRIS-3m generator, and an MDR-23 monochromator connected to a computer.

Laser ablation-inductively coupled plasma-mass spectrometry (LA-ICP-MS) was carried out at Johannes Gutenberg University in Mainz, Germany, with an ESI/NWR-193 laser system (193 nm) coupled to an Agilent 7500ce quadrupole ICP-MS with helium as the carrier gas. The laser spots had a diameter of $50 \mu \mathrm{m}$ on the samples and $100 \mu \mathrm{m}$ on the reference standards. Analyses were carried out at an energy density of $2.02 \mathrm{~J} / \mathrm{cm}^{-2}$ with a $10 \mathrm{~Hz}$ repetition rate, using NIST SRM 612 glass as an external standard and NIST SRM 610 as an unknown for quality control. ${ }^{27} \mathrm{Al}$, measured as $\mathrm{Al}_{2} \mathrm{O}_{3}$ by electron microprobe, was used as the internal standard for rubies. ${ }^{29} \mathrm{Si}$, based on $\mathrm{SiO}_{2}$ from electron microprobe data, was used for micas. Data reduction was carried out with Glitter commercial software. Detection limits were typically in the lower parts-per-billion range, and analytical uncertainties were generally between $5 \%$ and $15 \%$, based on the external reproducibility of the reference materials (Jacob, 2006). Microprobe analysis was carried out at the Fersman Mineralogical Museum of the Russian Academy of Sciences. For these analyses, we used a Link ISIS energy-dispersive spectrometer (EDS) electronic probe microanalyzer attached to a CamScan D4 scanning electron microscope.

\section{DESCRIPTION OF THE ROUGH}

Rough ruby and sapphire samples from the Snezhnoe deposit were found in different parts of mineralized zones and had a distinct appearance. Ruby and sapphire crystals within micaceous lenses were normally translucent - the intergrowth of transparent and translucent areas could be observed in some crystals - and displayed visible morphological defects, such as polysynthetic twinning and parting 


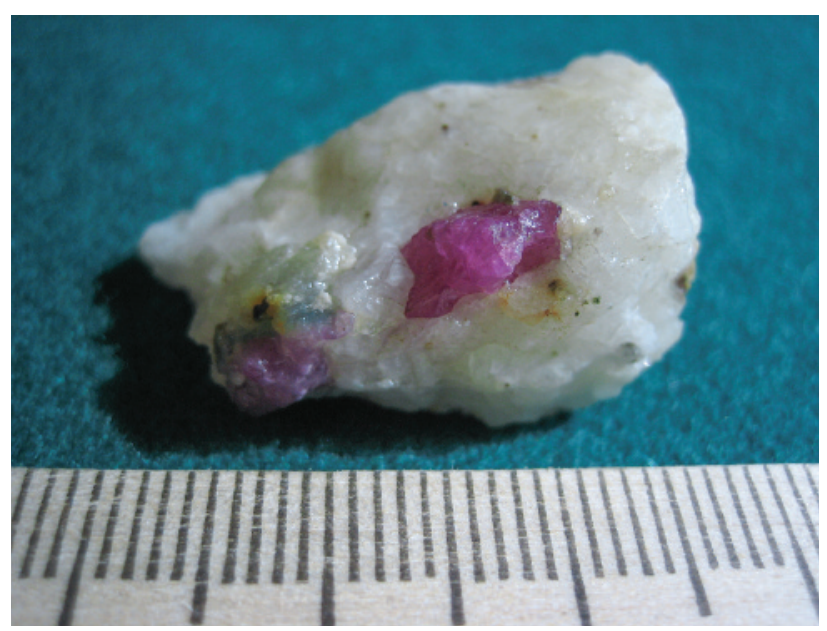

Figure 8. Ruby crystals within a $2 \mathrm{~cm}$ calcitic marble. Photo by Elena S. Sorokina.

parallel to the $c$, $a$, and $r$ corundum faces. As a result, they were usually unsuitable for faceting or even cabochons. Their morphology and color varied from purple elongated prisms to slightly pink prismatic rhombohedra and deep red pinacoid crystals. Dipyramids were also found in the samples. The average crystal size varied from 20 to $30 \mathrm{~mm}$, in rare instances reaching 50-60 $\mathrm{mm}$ in length.

At the Snezhnoe deposit, bright red gem-quality ruby crystals with a slightly purple hue are found in marble (figure 8). These samples were characterized by a prismatic habit with $c, r$, and $z$ faces, as well as irregular morphology with normally rounded faces (figure 9). Most of these samples were transparent and much shorter in length than the type found within micaceous lenses, often no longer than 8-10 $\mathrm{mm}$. The ruby crystals were free of visible morphological defects except for occasional parting, typically parallel to the $c$ and $r$ crystal faces.

\section{RESULTS AND DISCUSSION}

Gemological Characteristics. The gemological properties of rubies and sapphires from the Snezhnoe deposit were similar to those previously observed by other researchers (Henn and Bank, 1990; Smith, 1998 ) and quite typical for corundum overall (table 1).

The results of this study showed a refractive index of $\mathrm{n}_{\mathrm{o}}=1.762-1.764$ and $\mathrm{n}_{\mathrm{e}}=1.772-1.774$. Birefringence was 0.008-0.009. Specific gravity ranged from 3.99 to 4.01. Pleochroism was usually weak to medium for crystals from the micaceous lenses but strong in marble-hosted samples; dichroism was orange-red parallel to the c-axis and reddish violet perpendicular to the c-axis. The samples luminesced strong red under long-wave UV and weak red under short-wave UV.

Internal Growth Structure. Ruby and sapphire from micaceous lenses contained abundant defects. Purple and dark red specimens showed parting along the $r$

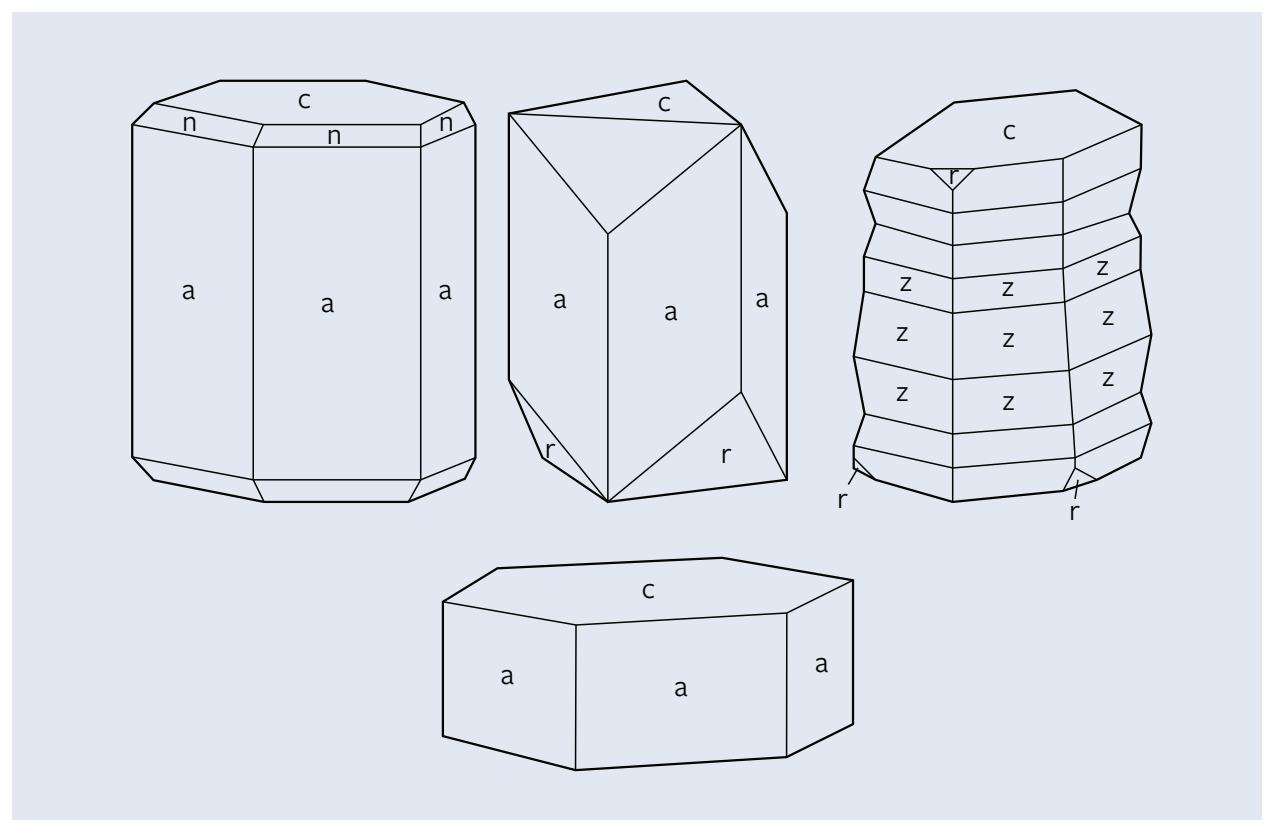

Figure 9. Crystal morphology of gem corundum from Snezhnoe. Top, left to right: an elongated prismatic habit with a, n, and c faces; a rhombohedralprismatic habit with a, $\mathrm{r}$, and c faces; and $a$ prismatic habit with $\mathrm{z}$, c, and $\mathrm{r}$ faces. Bottom: a pinacoid habit with c and a faces. Modified from Goldschmidt (1918). 
TABLE 1. Gemological properties of corundum from the Snezhnoe deposit compared with previous studies.

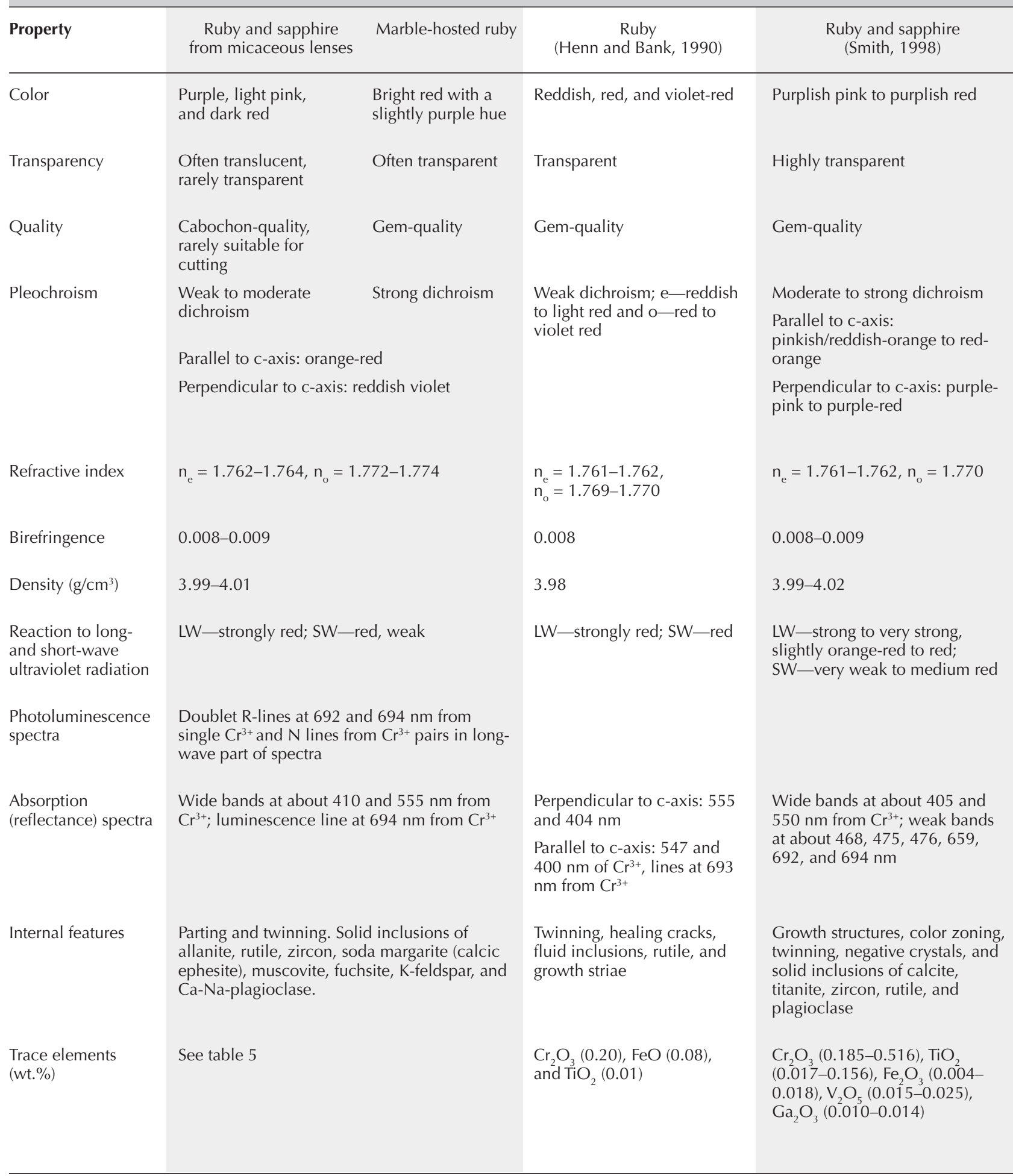

and $a$ faces, respectively. Pink sapphires exhibited polysynthetic twinning along the $r$ face. Marblehosted ruby did not show any visible defects, probably due to the recrystallization process, which may also explain their rounded faces.

Inclusions. Ruby and Sapphire from Micaceous Lenses. One of the most interesting findings of this 

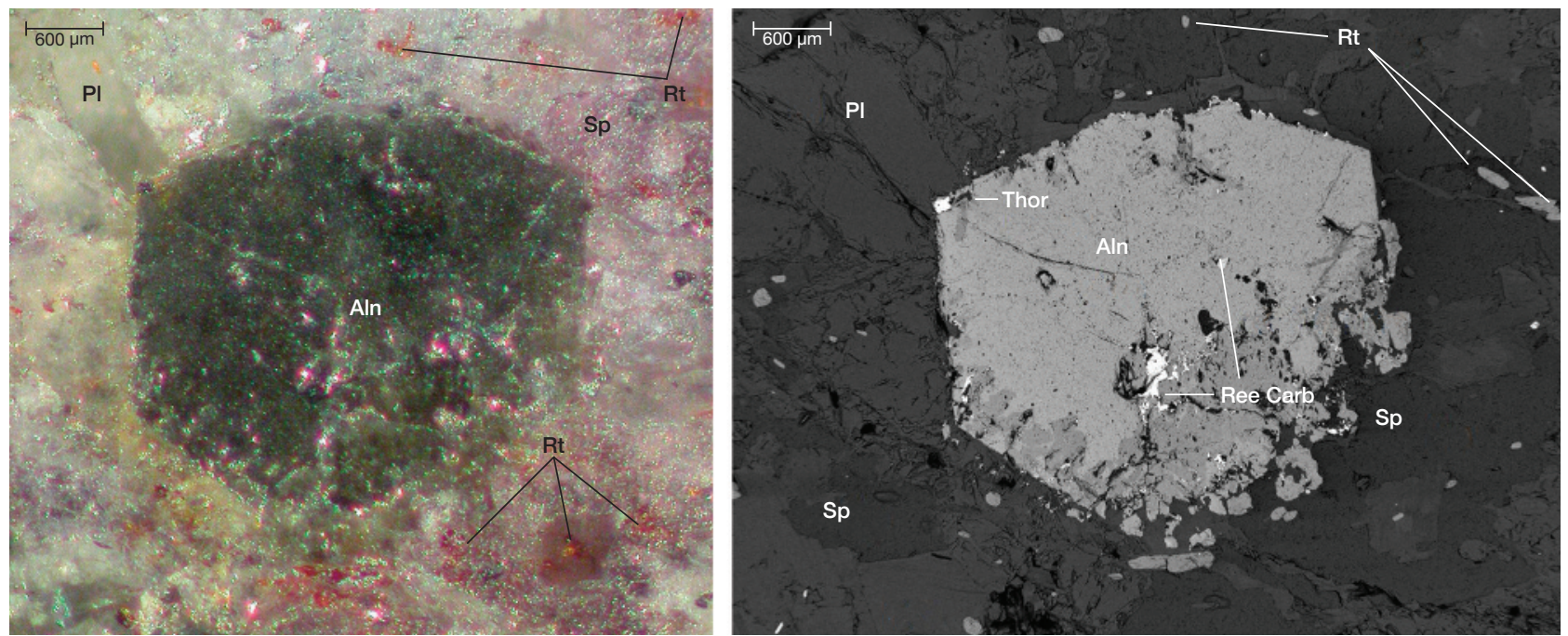

Figure 10. The photomicrograph on the left and the backscattered electron image on the right show a large allanite (Aln) crystal in contact with plagioclase (PI) and sapphire (Sp), small allanite (right bottom corner of the large allanite crystal), and rutile (Rt) in pink sapphire from Snezhnoe. REE carbonates (Ree Carb) and thorianite (Thor) are included in the allanite. Also seen are plagioclase (P1) and muscovite (Ms). Photomicrograph by Elena S.

Sorokina. The BSE image is from Sorokina et al. (2012).

study was that protogenetic inclusions of allanite were recognized in about $10 \%$ of the samples. Hexagonal allanite crystals with relicts of U-bearing thorianite and REE carbonates were also detected next to plagioclase and sapphire (Sorokina et al., 2012; figure 10). Inclusions and hexagonal crystals of allanite contained rare earth elements (table 2).

Another notable finding involved syngenetic particles and flakes of light blue mica (figure 11) with sizes varying from approximately 200 to $300 \mu \mathrm{m}$. Samples from Snezhnoe have previously been examined by X-ray powder diffraction, which identified diffraction lines close to margarite mica.

Using data from microprobe analyses, we found that the main mica cations were $\mathrm{Ca}$ and $\mathrm{Na}$. The ratio of their ions was approximately 1:1. In a few samples, $\mathrm{Na}$ ions outnumbered $\mathrm{Ca}$, reaching the ionic number of 0.59 in structural formula (table 3).

To identify the chemical elements that compensated the charge of the $\mathrm{Na}$ ions replacing $\mathrm{Ca}$ within the mica structure, we turned to LA-ICP-MS (table 4). These analyses showed an additional Li component, a finding that would have been impossible to determine by electron microprobe (see Schaller et al., 1967, and references therein). The maximum concentration of Li within mica is about $2020 \mathrm{ppm}$. Moreover, we detected $\mathrm{Cr}$ and $\mathrm{Sr}$ up to $2186 \mathrm{ppm}$ and $1518 \mathrm{ppm}$, respectively. Therefore, the blue mineral inclusions are mica of the margarite-ephesite series-calcic ephesite or soda margarite, enriched with $\mathrm{Cr}$ and $\mathrm{Sr}$.

We also observed rounded, transparent inclusions (probably protogenetic) that were previously identified as zircon (Smith, 1998). The zircon inclusions, ranging from approximately 50 to $70 \mu \mathrm{m}$ in size, showed high relief and strong interference colors. $\mathrm{HfO}_{2}$, up to $2.05 \mathrm{wt} . \%$, was detected in the composition of this solid inclusion (see again table 2).

High-relief particles of dark brown rutile were observed as syngenetic inclusions (previously detected by Henn and Bank, 1990), ranging from approximately 150 to $300 \mu \mathrm{m}$ (figure 12). They showed twinning with an angle of about $115^{\circ}$. The rutile inclusions were nor-

Figure 11. This backscattered electron image shows particles of blue mica and rutile (Rt) inclusions in ruby (Rb) from Snezhnoe. From Sorokina (2011).

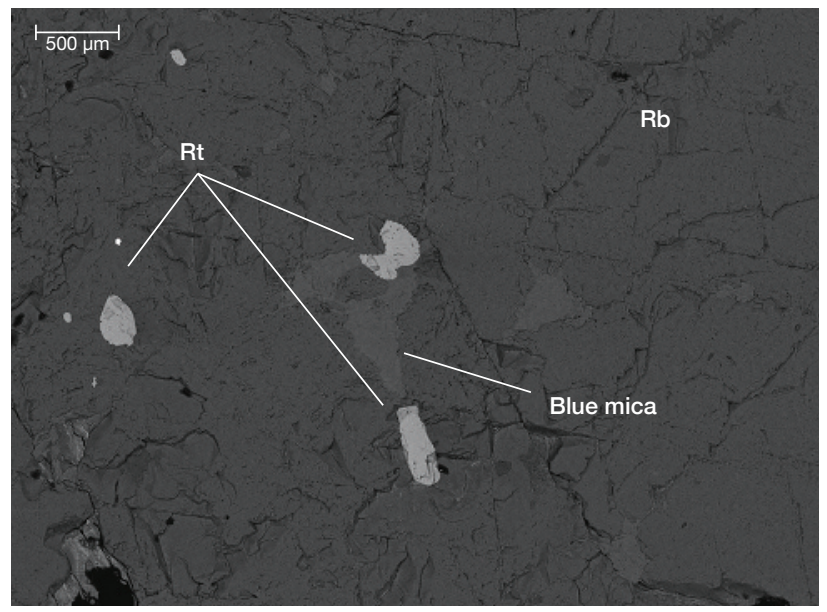


TABLE 2. Composition of solid inclusions within corundum from Snezhnoe by electron microprobe analysis. ${ }^{\mathrm{a}, \mathrm{b}, \mathrm{c}}$

\begin{tabular}{|c|c|c|c|c|c|c|}
\hline $\begin{array}{l}\text { Oxides } \\
\text { (wt.\%) }\end{array}$ & $\begin{array}{l}\text { Allanite } \\
(\mathrm{n}=6)^{\mathrm{a}}\end{array}$ & $\begin{array}{l}\text { Thorianite } \\
\quad(n=3)\end{array}$ & $\begin{array}{c}\text { REE } \\
\text { carbonate } \\
\qquad(\mathrm{n}=1)\end{array}$ & $\begin{array}{c}\text { Zircon } \\
(\mathrm{n}=2)\end{array}$ & $\begin{array}{l}\text { Rutile } \\
(n=2)\end{array}$ & $\begin{array}{c}\text { Fuchsite } \\
(\mathrm{n}=1)\end{array}$ \\
\hline $\begin{array}{l}\mathrm{H}_{2} \mathrm{O} \\
\text { (calculated) }\end{array}$ & 1.47 & - & 13.55 & - & - & - \\
\hline $\begin{array}{l}\mathrm{CO}_{2} \\
\text { (calculated) }\end{array}$ & - & - & 24.83 & - & - & - \\
\hline $\mathrm{Na}_{2} \mathrm{O}$ & - & - & - & - & - & 3.88 \\
\hline $\mathrm{MgO}$ & $0.56-1.29(0.87)^{b}$ & 0.12 & - & - & - & 1.01 \\
\hline $\mathrm{Al}_{2} \mathrm{O}_{3}$ & $20.45-23.81(33.07)$ & 0.17 & 1.06 & - & - & 35.51 \\
\hline $\mathrm{SiO}_{2}$ & $32.42-34.58(33.07)$ & 0.27 & 1.5 & $30.13-31.50(30.82)$ & - & 45.28 \\
\hline $\mathrm{K}_{2} \mathrm{O}$ & - & - & - & - & - & 6.04 \\
\hline $\mathrm{CaO}$ & $12.19-15.13(12.82)$ & 0.15 & 0.73 & - & - & 0.82 \\
\hline $\mathrm{TiO}_{2}$ & bdl-0.5 (0.23) & - & - & - & 98.33-98.94 (98.64) & - \\
\hline $\mathrm{MnO}$ & bdl-0.39 (0.16) & - & - & - & - & - \\
\hline $\mathrm{Cr}_{2} \mathrm{O}_{3}$ & - & - & - & - & $0.49-0.81(0.65)$ & 0.93 \\
\hline $\mathrm{FeO}$ & - & - & 0.21 & - & - & - \\
\hline $\mathrm{Fe}_{2} \mathrm{O}_{3}$ & $5.32-9.2(8.0)$ & - & - & - & - & - \\
\hline $\mathrm{ZrO}_{2}$ & - & - & - & $63.98-66.46(65.22)$ & - & - \\
\hline $\mathrm{Y}_{2} \mathrm{O}_{3}$ & bdl-0.39 (0.24) & - & 0.48 & - & - & - \\
\hline $\mathrm{La}_{2} \mathrm{O}_{3}$ & $3.7-6.14(4.84)$ & - & 11.36 & - & - & - \\
\hline $\mathrm{Hf}_{2} \mathrm{O}$ & - & - & - & bdl-2.06 (1.03) & - & - \\
\hline $\mathrm{Ce}_{2} \mathrm{O}_{3}$ & 7.93-11.08 (9.99) & 0.21 & 29.32 & - & - & - \\
\hline $\mathrm{Pr}_{2} \mathrm{O}_{3}$ & $0.34-1.31(0.86)$ & - & 3.2 & - & - & - \\
\hline $\mathrm{Nd}_{2} \mathrm{O}_{3}$ & $3.03-4.19(3.55)$ & - & 12.45 & - & - & - \\
\hline $\mathrm{Sm}_{2} \mathrm{O}_{3}$ & $0.19-0.85(0.48)$ & - & 1.15 & - & - & - \\
\hline $\mathrm{Gd}_{2} \mathrm{O}_{3}$ & $0.19-0.82(0.48)$ & 0.30 & 1.15 & - & - & - \\
\hline $\mathrm{ThO}_{2}$ & $0.55-1.0(0.81)$ & 80.36 & 0.86 & - & - & - \\
\hline $\mathrm{UO}_{2}$ & bdl-0.15 (0.03) & 17.52 & - & - & - & - \\
\hline Total & 99.32-100.34 (99.57) & 99.1 & 102.37 & $94.12-100.0(97.06)$ & 98.95-99.75 (99.35) & 93.86 \\
\hline
\end{tabular}



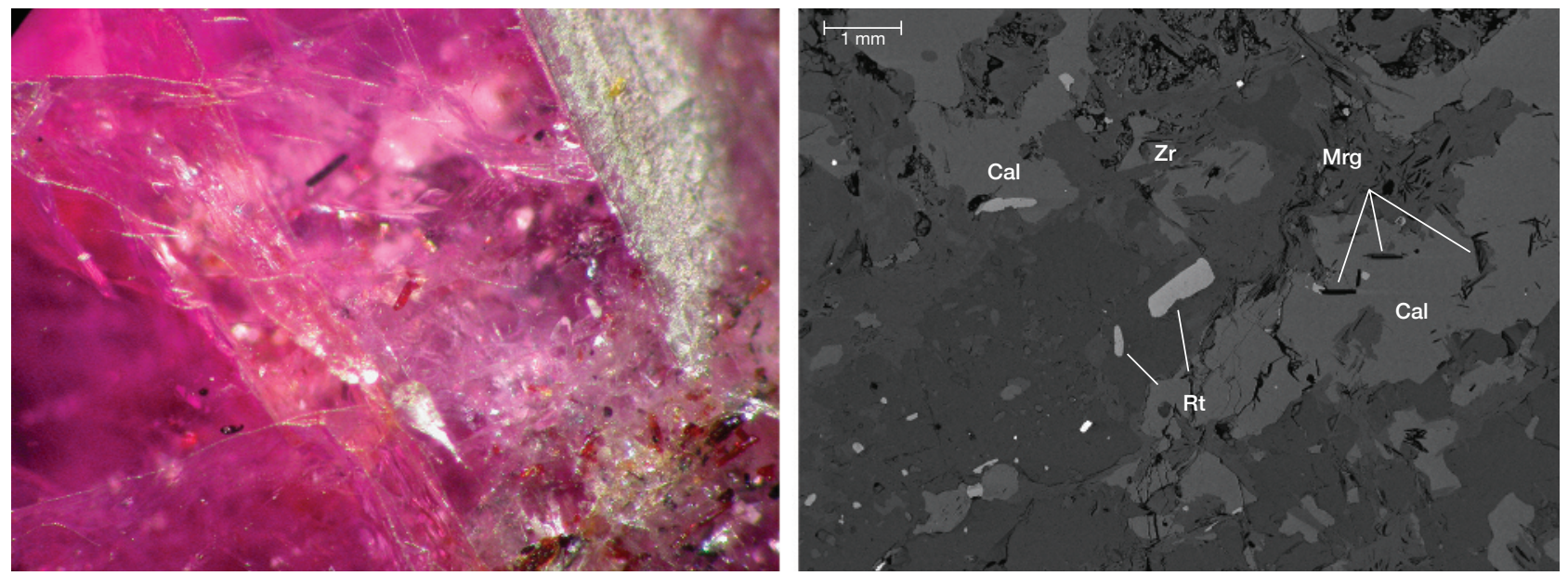

Figure 12. Left: Brown prismatic rutile inclusions within ruby from Snezhnoe. Photomicrograph by Elena S. Sorokina, magnified 35x. Right: A backscattered electron image of zircon ( $\mathrm{Zr}$ ) and rutile (Rt) inclusions in pink sapphire from the deposit (Cal = calcite, $\mathrm{Mrg}=$ margarite). From Sorokina (2011).

mally enriched with Cr (up to $0.81 \mathrm{wt} . \%$; table 2 ).

also detected the transparent irregular form of

Similar to previous studies (e.g., Smith, 1998), we feldspar inclusions within ruby crystals. Two types

TABLE 3. Chemical composition of mica inclusions of the margarite-ephesite series by electron microprobe analysis. ${ }^{a, b}$

\begin{tabular}{|c|c|c|c|c|c|c|c|c|c|c|}
\hline $\begin{array}{l}\text { Oxides } \\
\text { (wt.\%) }\end{array}$ & $\begin{array}{c}\text { Sample } \\
1\end{array}$ & $\begin{array}{c}\text { Sample } \\
2\end{array}$ & $\begin{array}{c}\text { Sample } \\
3\end{array}$ & $\begin{array}{c}\text { Sample } \\
4\end{array}$ & $\begin{array}{c}\text { Sample } \\
5\end{array}$ & $\begin{array}{c}\text { Sample } \\
6\end{array}$ & $\begin{array}{c}\text { Sample } \\
7\end{array}$ & $\begin{array}{c}\text { Sample } \\
8\end{array}$ & $\begin{array}{c}\text { Sample } \\
9\end{array}$ & $\begin{array}{c}\text { Sample } \\
10\end{array}$ \\
\hline $\mathrm{Na}_{2} \mathrm{O}$ & 3.95 & 3.74 & 3.44 & 3.97 & 4.67 & 3.97 & 3.92 & 3.23 & 4.72 & 3.29 \\
\hline $\mathrm{MgO}$ & 0.53 & 0.36 & 0.52 & 0.54 & 0.67 & 0.56 & 0.65 & 0.54 & 0.35 & 0.51 \\
\hline $\mathrm{Al}_{2} \mathrm{O}_{3}$ & 47.35 & 45.21 & 48.19 & 46.29 & 45.69 & 47.39 & 45.94 & 45.60 & 37.13 & 47.15 \\
\hline $\mathrm{SiO}_{2}$ & 35.91 & 37.04 & 35.62 & 36.34 & 38.75 & 35.61 & 38.80 & 36.72 & 48.57 & 36.19 \\
\hline $\mathrm{K}_{2} \mathrm{O}$ & 0.40 & 0.73 & 0.66 & 0.42 & 0.64 & 0.26 & 0.94 & 1.20 & 2.32 & 0.55 \\
\hline $\mathrm{CaO}$ & 7.09 & 5.89 & 7.52 & 6.55 & 5.48 & 7.10 & 6.21 & 6.64 & 0.27 & 7.17 \\
\hline $\mathrm{Fe}_{2} \mathrm{O}_{3}$ & bdl & 0.23 & 0.27 & 0.32 & 0.38 & 0.33 & 0.44 & 0.42 & 0.38 & bdl \\
\hline Total & 95.41 & 93.19 & 96.21 & 94.43 & 96.28 & 95.23 & 96.90 & 94.34 & 93.73 & 95.00 \\
\hline \multirow[t]{2}{*}{ Cations } & Sample & Sample & Sample & Sample & Sample & Sample & Sample & Sample & Sample & Sample \\
\hline & 1 & 2 & 3 & 4 & 5 & 6 & 7 & 8 & 9 & 10 \\
\hline $\mathrm{Na}$ & 0.50 & 0.48 & 0.43 & 0.51 & 0.58 & 0.51 & 0.49 & 0.41 & 0.59 & 0.42 \\
\hline Mg & 0.05 & 0.04 & 0.05 & 0.05 & 0.06 & 0.05 & 0.06 & 0.05 & 0.03 & 0.05 \\
\hline $\mathrm{Al}$ & 3.65 & 3.55 & 3.69 & 3.60 & 3.47 & 3.66 & 3.48 & 3.55 & 2.83 & 3.64 \\
\hline $\mathrm{Si}$ & 2.35 & 2.47 & 2.31 & 2.40 & 2.50 & 2.33 & 2.49 & 2.43 & 3.14 & 2.37 \\
\hline $\mathrm{K}$ & 0.03 & 0.06 & 0.05 & 0.04 & 0.05 & 0.02 & 0.08 & 0.10 & 0.19 & 0.05 \\
\hline $\mathrm{Ca}$ & 0.50 & 0.42 & 0.52 & 0.46 & 0.38 & 0.50 & 0.43 & 0.47 & 0.02 & 0.50 \\
\hline $\mathrm{Fe}^{3+}$ & - & 0.01 & 0.01 & 0.02 & 0.02 & 0.02 & 0.02 & 0.02 & 0.02 & - \\
\hline Total & 7.08 & 7.03 & 7.08 & 7.07 & 7.07 & 7.09 & 7.04 & 7.04 & 6.83 & 7.04 \\
\hline
\end{tabular}

a The structural formula of mica of the margarite-ephesite series is based on 11 atoms of oxygen.

${ }^{b}$ bdl = below detection limit 

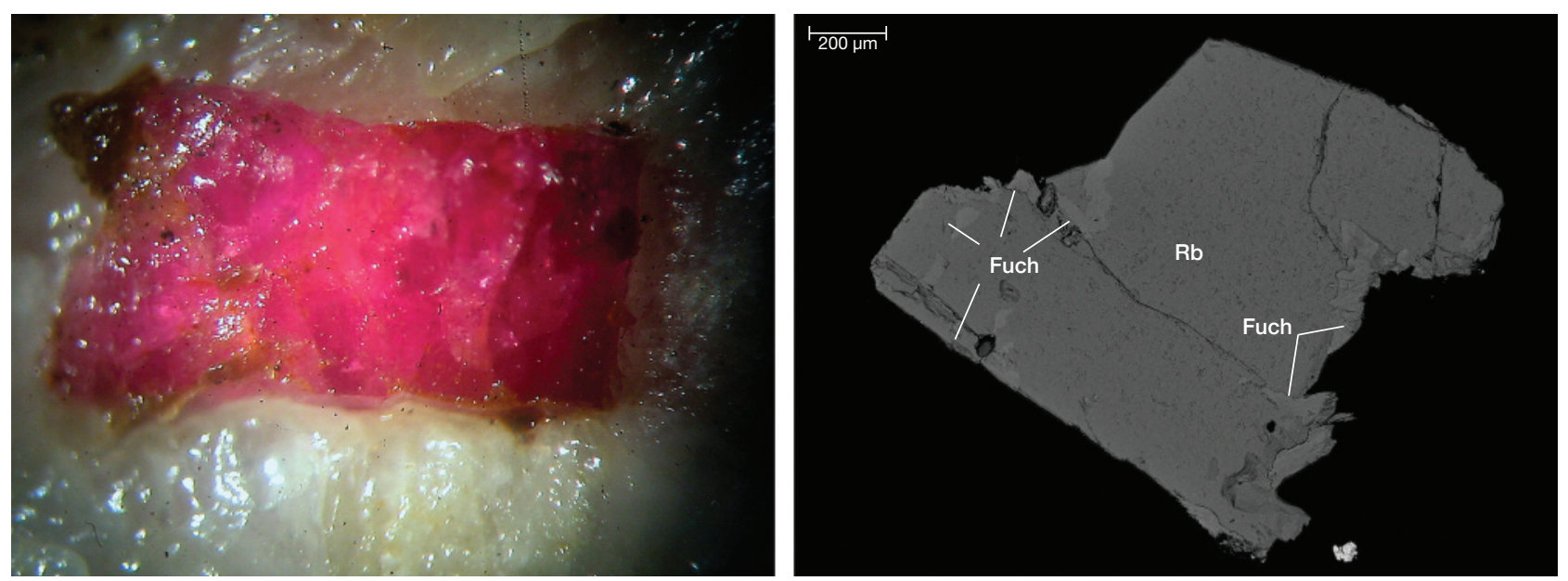

Figure 13. Left: Intergrowth of a $0.2 \mathrm{~cm}$ ruby crystal and green fuchsite within a white calcitic matrix. Photomicrograph by Elena S. Sorokina. Right: A backscattered electron image showing solid inclusions of fuchsite (Fuch) within ruby (Rb). From Sorokina (2011).

of feldspar were detected: K-feldspar (microcline) and $\mathrm{Ca}-\mathrm{Na}$ plagioclase (labradorite-anorthite). Most of the feldspar inclusions were twinned, measuring approximately 300 to $400 \mu \mathrm{m}$. Their birefringence was 0.006-0.007; relief was low, with crystals showing cleavages in two directions.

Ruby from Marbles. Flakes of fuchsite with $\mathrm{Cr}_{2} \mathrm{O}_{3}$ concentration above $1 \mathrm{wt}$ \% (Deer et al., 1962) and intergrowths of green muscovite and fuchsite were detected within this type of ruby sample (figure 13 and table 2). The birefringence in thin sections ranged up to 0.027 . Flakes of these mica inclusions were replaced in part by a green mineral of the chlorite group, probably prochlorite.

Smith (1998) previously identified other solid inclusions in rubies and sapphires from the Snezhnoe deposit, such as calcite and titanite. Although margarite is a common inclusion for gem corundum, the discovery of mica of the margarite-ephesite series (calcic ephesite or soda margarite) has not been reported in ruby, to the best of our knowledge (Gübelin and Koivula, 1986, and references therein; Hughes, 1997). Moreover, allanite is rarely detected in corundum (Hänni, 1990; Sutherland et al., 2008), and along with muscovite and fuchsite it has not been reported within ruby and sapphire from Snezhnoe until now. Therefore, these features can be used together with zircon, rutile, and feldspar inclusions to distinguish these gemstones from Tajikistan.

Chemical Composition. To study the composition of ruby and sapphire from Snezhnoe, we performed LAICP-MS analysis on 22 elements and electron microprobe analysis for Fe (table 5). The results showed that quantities of chromophores such as $\mathrm{Ti}, \mathrm{V}, \mathrm{Cr}$, and $\mathrm{Fe}$ were within the normal range for ruby of similar formation type (table 6). The samples from mica-

TABLE 4. Trace-element composition (ppmw) of mica of the margarite-ephesite series by LA-ICP-MS.

\begin{tabular}{cccccccccccccccccccccccc}
\hline $\begin{array}{c}\text { Sample } \\
\text { no. }\end{array}$ & $\mathrm{Li}$ & $\mathrm{Be}$ & $\mathrm{B}$ & $\mathrm{Na}$ & $\mathrm{Mg}$ & $\begin{array}{c}\mathrm{SiO}_{2}{ }^{*} \\
(\mathrm{wt} . \%)\end{array}$ & $\mathrm{K}$ & $\mathrm{Ca}$ & $\mathrm{Sc}$ & $\mathrm{Ti}$ & $\mathrm{V}$ & $\mathrm{Cr}$ & $\mathrm{Mn}$ & $\mathrm{Co}$ & $\mathrm{Ni}$ & $\mathrm{Zn}$ & $\mathrm{Ga}$ & $\mathrm{Rb}$ & $\mathrm{Sr}$ & $\mathrm{Ba}$ \\
\hline 1 & 1662 & 15 & 116 & 29,722 & 2157 & 36.74 & 7539 & 39,535 & 9.97 & 292 & 120 & 2186 & 2.50 & 1.40 & 11.5 & 21.0 & 74.8 & 16.7 & 1518 & 410 \\
2 & 2020 & 18 & 127 & 30,049 & 2222 & 36.74 & 4163 & 45,066 & 8.94 & 306 & 126 & 909 & 4.80 & 1.50 & 10.4 & 29.8 & 60.3 & 10.9 & 1201 & 116 \\
3 & 1956 & 13 & 107 & 31,870 & 2246 & 36.74 & 4706 & 40,585 & 8.45 & 317 & 123 & 605 & 4.80 & 1.20 & 10.1 & 23.4 & 54.6 & 13.1 & 1164 & 102 \\
Average & 1879 & 15 & 116 & 30,547 & 2208 & 36.74 & 5469 & 41,728 & 9.12 & 305 & 123 & 1233 & 4.00 & 1.30 & 10.7 & 24.7 & 63.2 & 13.6 & 1294 & 209
\end{tabular}

* $\mathrm{SiO}_{2}$ composition was determined by electron microprobe analysis. 
TABLE 5. Trace-element composition (ppmw) of corundum from Snezhnoe, by LA-ICP-MS.a,b,c

\begin{tabular}{|c|c|c|c|c|}
\hline \multirow{2}{*}{$\begin{array}{l}\text { Chemical } \\
\text { element }\end{array}$} & \multicolumn{3}{|c|}{ From micaceous lenses } & \multirow{2}{*}{$\begin{array}{l}\text { From marble } \\
\text { Bright red ruby with a slightly } \\
\text { purple hue }(n=6)\end{array}$} \\
\hline & $\begin{array}{l}\text { Purple sapphire } \\
\qquad(\mathrm{n}=3)\end{array}$ & $\begin{array}{l}\text { Slightly pink sapphire } \\
\qquad(\mathrm{n}=8)\end{array}$ & $\begin{array}{l}\text { Dark red ruby } \\
\qquad(\mathrm{n}=3)\end{array}$ & \\
\hline $\mathrm{Cr}$ & 416-661 (530) & $687-1775$ (1077) & 2012-2820 (2376) & 1696-4204 (3190) \\
\hline $\mathrm{Ti}$ & $17.2-50.3(28.5)$ & $52.5-165(92)$ & $30.8-69.9(49.3)$ & $5.7-75.4(31.5)$ \\
\hline V & $38.4-41.0(39.7)$ & $37.5-49.2(43.1)$ & $93.0-95.1(93.7)$ & 51.5-122 (95.3) \\
\hline $\mathrm{Ga}$ & $52.5-56.9(55.1)$ & $53.4-63.3(59)$ & $67.2-87.6(79.1)$ & $60.9-83.4(71.3)$ \\
\hline $\mathrm{Fe}^{\mathrm{b}}$ & bdl & bdl & bdl & bdl \\
\hline $\mathrm{Mg}$ & $12.3-24.6(17.97)$ & $17.7-898$ (205) & 16. 6-35.9 (24.2) & $3.67-71.9$ (27.9) \\
\hline$M n$ & bdl-0.300 (0.1) & bdl-2.11 (0.61) & bdl-0.61 (0.34) & bdl-6.82 (1.75) \\
\hline $\mathrm{Ca}$ & bdl-296 (115) & bdl-4363 (1066) & bdl-188 (85.8) & $39.5-926(387)$ \\
\hline $\mathrm{Na}$ & bdl-8.19 (4.76) & 39.9-4764 (1182) & $34.3-176(85.3)$ & bdl-316 (59.8) \\
\hline $\mathrm{Si}$ & $1001-1724$ (1358) & $1217-28,407(10,731)$ & 1044-1645 (1300) & 869-3225 (1674) \\
\hline$P$ & $23.5-27.7$ (25.7) & 18.9-62.4 (33.6) & bdl-19.8 (10.6) & $15.4-34.7(23.2)$ \\
\hline K & bdl-13.6 (5.87) & $4.75-3833$ (668) & bdl-49.0 (19.5) & bdl-31.7 (9.23) \\
\hline Sc & bdl & bdl-0.441 (0.226) & bdl & bdl-0.531 (0.181) \\
\hline Co & bdl-0.174 (0.08) & bdl-2.98 (0.87) & bdl-0.069 (0.02) & bdl-0.393 (0.13) \\
\hline $\mathrm{Ni}$ & $0.490-4.04(1.7)$ & bdl-109 (22.6) & bdl & bdl-6.51 (2.95) \\
\hline $\mathrm{Cu}$ & $0.5-2.43(1.2)$ & bdl-228 (54.8) & bdl & bdl-22.6 (4.21) \\
\hline $\mathrm{Zn}$ & $1.14-6.21(3.63)$ & $1.49-129$ (26.8) & bdl-1.22 (0.4) & bdl-31.9 (11.4) \\
\hline $\mathrm{Ge}$ & bdl & bdl-1.69 (0.21) & bdl & bdl \\
\hline Mo & bdl & bdl-1.81 (0.42) & bdl & bdl \\
\hline La & bdl & bdl-0.380 (0.15) & bdl-0.052 (0.02) & bdl-0.248 (0.17) \\
\hline $\mathrm{Nd}$ & bdl & bdl-0.73 (0.14) & bdl & bdl-0.235 (0.04) \\
\hline W & bdl-0.284 (0.095) & bdl-0.201 (0.03) & bdl-0.187 (0.12) & bdl \\
\hline $\mathrm{Bi}$ & bdl-0.182 (0.08) & bdl-7.12 (1.97) & bdl & bdl-0.134 (0.02) \\
\hline
\end{tabular}

ceous lenses contained the following concentrations of trace elements: $416-2820$ ppm Cr, $17.2-165$ ppm Ti, 37-95 ppm V, and 52-87 ppm Ga. For marblehosted ruby, the ranges were: $1696-4204 \mathrm{ppm} \mathrm{Cr}$, 5.7-75 ppm Ti, 51-122 ppm V, and 60-83 ppm Ga. The highest $\mathrm{Cr}$ concentrations were observed in the bright red marble-hosted ruby. These values were close to those of other rubies of similar formation type, including samples from Mogok, Myanmar (analyzed by Muhlmeister et al., 1998; table 6).

Spectroscopy. Corundum from Snezhnoe ranges from purple (416-661 ppm Cr) to slightly pink (687-1775 ppm Cr) to dark red (2012-2820 ppm Cr). The range of ruby color includes the bright red with slightly purple hue known as "pigeon's blood" (1696-4204 ppm Cr). Reflectance spectra were recorded from these four different types. The common features were wide bands at about 410 and $555 \mathrm{~nm}$ and a line at 694, related to $\mathrm{Cr}^{3+}$ transitions (Marfunin, 1974; figure 14). Thus, we concluded that the main chromophore for these samples is $\mathrm{Cr}^{3+}$. A higher chromium concentration enhances the depth of red color from slightly pink to dark red to bright red with a hint of purple. Another possible chromophore for the purple sapphires is $\mathrm{V}^{3+}$; note the concentration of vanadium in table 5 . Difficulty in detecting the $\mathrm{V}^{3+}$ chromophore is caused by the low $\mathrm{V}^{3+}$ to $\mathrm{Cr}^{3+}$ ratio (table 5) and the superposition 


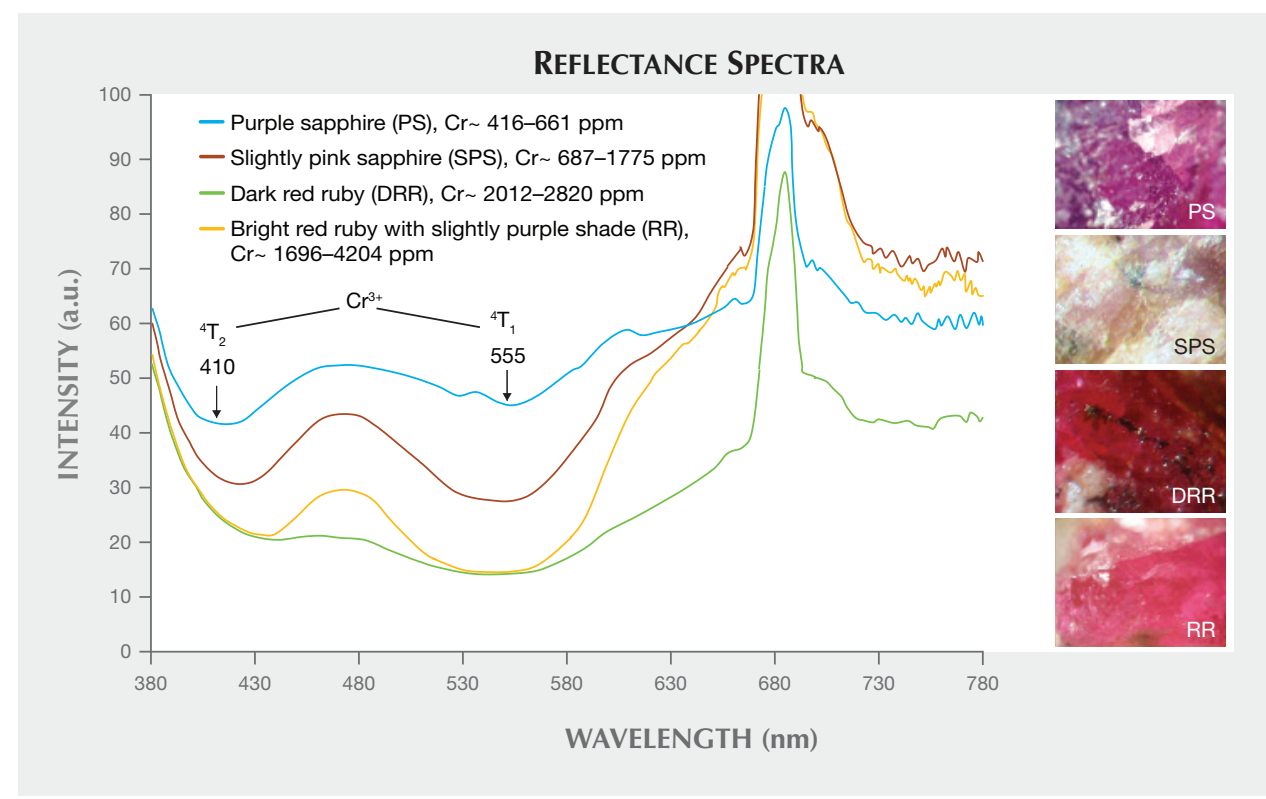

Figure 14. Typical re-

flectance spectra for the

different colors of corundum from Snezhnoe: purple sapphire (blue line, 416-661 ppm); slightly pink sapphire (red line, 6871775 ppm); dark red ruby (green line, 2012$2820 \mathrm{ppm}$ ); and bright red ruby (orange line, 1696-4204 ppm). Modified from Sorokina (2011).

of their absorption bands (Schmetzer and Bank, 1981; Platonov et al., 1984).

Luminescence spectra commonly show an R-line of single $\mathrm{Cr}^{3+}$ at $692 \mathrm{~nm}$ and a few $\mathrm{N}$-lines of $\mathrm{Cr}^{3+}$ pairs at around the 699-710 nm (Taraschan, 1978; figure 15). The intensity of luminescence increased with Cr content in the samples. The highest intensity was observed in bright red ruby.

\section{CONCLUSIONS}

Located high in the Pamir Mountains of Tajikistan, the Snezhnoe deposit is a unique source of corundum, including various colors of pink to purple sapphire and "pigeon's blood" ruby. Although its reserves of gemquality corundum are estimated at many hundred thousand carats, the occurrence has seen only limited study. This article reviewed the geology of Snezhnoe and characterized the corundum from this source. We reported gemological features (RI, birefringence, densitvy, pleochroism, dichroism, and photoluminescence) very similar to those previously published by Henn and Bank (1990) and Smith (1998). $\mathrm{Cr}^{3+}$ bands

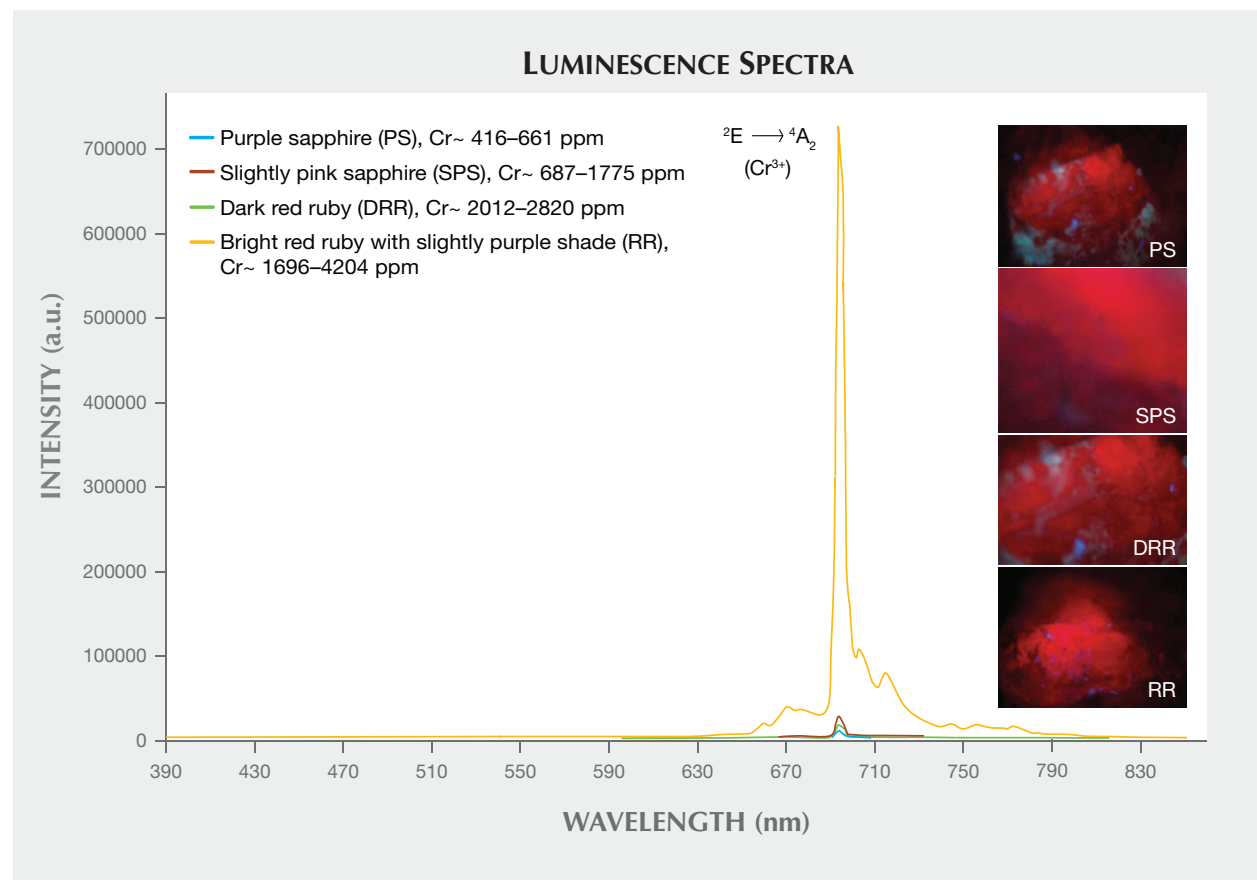

Figure 15. Typical luminescence spectra of the different types of corundum samples from Snezhnoe: purple sapphire (blue line, 416661 ppm Cr), slightly pink sapphire (red line, 687-1775 ppm Cr), dark red ruby (green line, 2012-2820 ppm $\mathrm{Cr})$, and bright red ruby (orange line, 1696-4204 ppm Cr). Modified from Sorokina (2011). 
TABLE 6. Chemical composition of marble-hosted ruby from various deposits by LA-ICP-MS ${ }^{\mathrm{a}}$, EDXRF, and EDSc analyses.

\begin{tabular}{|c|c|c|c|c|c|c|c|}
\hline $\begin{array}{l}\text { Oxide } \\
\text { (wt.\%) }\end{array}$ & $\begin{array}{c}\text { Snezhnoe, } \\
\text { Tajikistan } \\
(\mathrm{n}=6)\end{array}$ & $\begin{array}{l}\text { Luc Yen, } \\
\text { Vietnam } \\
(\mathrm{n}=1)\end{array}$ & $\begin{array}{l}\text { Afghanistan } \\
\quad(\mathrm{n}=15)\end{array}$ & $\begin{array}{l}\text { Mogok, } \\
\text { Myanmar } \\
(\mathrm{n}=19)\end{array}$ & $\begin{array}{c}\text { Mong Hsu, } \\
\text { Myanmar } \\
(\mathrm{n}=11)\end{array}$ & $\begin{array}{l}\text { Nepal } \\
(\mathrm{n}=3)\end{array}$ & $\begin{array}{c}\text { Southern Yunnan, } \\
\text { China } \\
(\mathrm{n}=2)\end{array}$ \\
\hline $\mathrm{TiO}_{2}$ & $\begin{array}{c}0.0009-0.011 \\
(0.0064)\end{array}$ & 0.02 & $\begin{array}{c}0.009-0.091 \\
(0.045)\end{array}$ & $\begin{array}{c}0.015-0.047 \\
(0.026)\end{array}$ & $\begin{array}{c}0.019-0.207 \\
(0.078)\end{array}$ & $\begin{array}{c}0.059-0.096 \\
(0.080)\end{array}$ & $\begin{array}{c}0.007-0.024 \\
(0.016)\end{array}$ \\
\hline $\mathrm{V}_{2} \mathrm{O}_{3}$ & $\begin{array}{c}0.0076-0.0179 \\
(0.0166)\end{array}$ & 0.01 & $\begin{array}{c}\text { bdl-0.016 } \\
(0.009)\end{array}$ & $\begin{array}{c}0.028-0.171 \\
(0.066)\end{array}$ & $\begin{array}{c}0.024-0.104 \\
(0.048)\end{array}$ & $\begin{array}{c}0.014-0.024 \\
(0.017)\end{array}$ & $\begin{array}{c}0.017-0.022 \\
(0.020)\end{array}$ \\
\hline $\mathrm{Cr}_{2} \mathrm{O}_{3}$ & $\begin{array}{c}0.2476-0.6138 \\
(0.5545)\end{array}$ & 0.37 & $\begin{array}{c}0.205-0.575 \\
(0.350)\end{array}$ & $\begin{array}{c}0.255-1.02 \\
(0.562)\end{array}$ & $\begin{array}{c}0.576-1.16 \\
(0.887)\end{array}$ & $\begin{array}{c}0.190-0.347 \\
(0.260)\end{array}$ & $\begin{array}{c}0.608-1.29 \\
(0.950)\end{array}$ \\
\hline $\mathrm{FeO}$ & bdl & - & $\begin{array}{c}0.009-0.133 \\
(0.070)\end{array}$ & $\begin{array}{c}0.006-0.080 \\
(0.028)\end{array}$ & $\begin{array}{c}\text { bdl-0.022 } \\
\quad(0.010)\end{array}$ & $\begin{array}{c}0.012-0.038 \\
(0.029)\end{array}$ & $\begin{array}{c}0.012-0.072 \\
(0.042)\end{array}$ \\
\hline $\mathrm{Fe}_{2} \mathrm{O}_{3}$ & bdl & 0.02 & - & - & - & - & - \\
\hline $\mathrm{Ga}_{2} \mathrm{O}_{3}$ & $\begin{array}{c}0.0082-0.0112 \\
(0.0097)\end{array}$ & 0.01 & $\begin{array}{c}\text { bdl-0.011 } \\
(0.006)\end{array}$ & $\begin{array}{c}\text { bdl-0.026 } \\
(0.012)\end{array}$ & $\begin{array}{c}\text { bdl-0.014 } \\
(0.009)\end{array}$ & $\begin{array}{c}0.009-0.025 \\
(0.018)\end{array}$ & 0.008 \\
\hline
\end{tabular}

${ }^{a}$ Oxide values for Tajik rubies are recalculated from table $5 ; n=$ number of measurements; minimum and maximum values are given, along with average (in parentheses); bdl = below detection limit.

${ }^{b}$ Values for rubies from Afghanistan, Myanmar, Nepal, and southern Yunnan are from Muhlmeister et al. (1998).

c Values for Vietnamese rubies are from Pham et al. (2004).

and lines were common features recorded in the luminescence and reflectance spectra for the ruby and sapphire. Previously undocumented solid inclusions of mica from the margarite-ephesite series were found in our samples. Inclusions such as allanite, muscovite, and fuchsite were discovered for the first time within corundum from Snezhnoe, to the best of our knowledge. These can be used along with other inclusions (zircon, rutile, K-feldspar, and Ca-Na-plagioclase) for possible origin identification of rubies and sapphires from Snezhnoe. LA-ICP-MS detected 22 trace elements, including the main chromophores $(\mathrm{Cr}, \mathrm{V}$, and
Ti) and a common trace element in natural corundum (Ga). The concentration values were within acceptable range for isomorphic impurities in the mineral structure. The highest $\mathrm{Cr}$ concentrations were observed in the bright red marble-hosted ruby, which had a value close to those of similar genetic type, including the famous Burmese rubies from Mogok.

As we continue to learn more about marblehosted ruby occurrences in Central Asia, further investigations remain necessary to better understand the genetic nature of the Snezhnoe deposit and the geological processes that took place there long ago.

\section{ABOUT THE AUTHORS}

Dr. Sorokina (elensorokina@mail.ru) is a research fellow at the Fedorovsky All-Russian Research Institute of Mineral Resources (FGUP VIMS) and the Fersman Mineralogical Museum of the Russian Academy of Sciences in Moscow. Dr. Litvinenko is professor and gemology chair at the Russian State Geological Prospecting University and director of GIA Moscow. Dr. Hofmeister is professor and vice president of research at Johannes Gutenberg University in Mainz, Germany, director of the university's department of gem-materials sciences and gemology, and head of the Centre for Gemstone Research in Idar-Oberstein, Germany. Dr. Häger is a senior scientist at the Centre for Gemstone Research at Johannes Gutenberg University, lecturer in the gemstone and jewellery design department at the University for Applied Sciences and managing director at the Centre for Gem- stones Research in Idar-Oberstein. Dr. Jacob is an associate professor in the department of earth and planetary sciences at Macquarie University in North Ryde, Australia. Dr. Nasriddinov is dean of the department of geosciences at the Mining and Metallurgy Institute in Chkalovsk of Tajikistan.

\section{ACKNOWLEDGMENTS}

The authors thank our colleagues Prof. Dr. Elena G. Ozhogina, Drs. Vadim V. Moroshkin and Victor A. Rassulov, Mrs. Anastasia V. Iospa from FGUP VIMS, Dr. Mikhail N. Kandinov from Vernadsky Geological Museum, and Mr. Leonid A. Pautov, Drs. Atali A. Agakhanov and Vladimir Yu. Karpenko from Fersman Mineralogical Museum for their assistance in sample collection, collaborations on analytical studies, and discussion of the manuscript. We also thank the anonymous reviewers for their helpful suggestions. 


\section{REFERENCES}

Barkhatov B.P. (1963) Tectonics of the Pamirs. Leningrad University, USSR [in Russian].

Bowersox G. (2005) July-August, 2005 Hindu Kush/Pamir Mountains Expedition. http://www.gems-afghan.com/cgi-bin/aslides.pl?12\&1.

Budanova K.T. (1991) Metamorphic Formations of Tajikistan. Donish Publishers, Dushanbe, Tajikistan (in Russian).

Budanova K.T. (1993) Mineralogical petrochemical characterization of high-alumina rocks in eastern part of central Pamirs. Izvestiya of Tajikistan AS (Proceedings of the Tajikistan Academy of Sciences), No. 1, pp. 26-33 [in Russian].

Deer W.A., Howie R.A., Zussman J. (1962) Rock-Forming Minerals, Volume 3: Sheet Silicates. Wiley, New York.

Dmitriev E.A. (1983) Types of corundum mineralization in the Precambrian marbles of the Muzkol-Rangkulsky anticlinorium. In A.V. Klimkin, Proceedings on Geology and Prospecting of the Gemstone Deposits of Tajikistan. Donish Publishers, Dushanbe, Tajikistan, pp. 34-36 [in Russian].

Dmitriev E.A., Ishan-Sho G.A. (1987) Chromium-bearing muscovites in metamorphic and hydrothermal formations of the Pamirs. Zapiski VMO (Proceedings of the All-Union Mineralogical Society), Vol. 116, No. 6, pp. 690-697 [in Russian].

Dufour M.S., Kol'tsov A.B., Zolotarev A.A., Kuznetsov A.B. (2007) Corundum-bearing metasomatic rocks in the Central Pamirs. Petrology, Vol. 15, No. 2, pp. 151-167, http://dx.doi.org/10.1134/ S0869591107020038

Giuliani G., Ohnenstetter D., Garnier V., Rakotondrazafy M., Schwarz D. (2007) The geology and genesis of gem corundum deposits. In L.A. Groat, Ed., Geology of Gem Deposits. Mineralogical Association of Canada, Quebec, pp. 23-78.

Goldschmidt V. (1918) Atlas der Krystallformen. Band V., Heidelberg.

Gübelin E.J., Koivula J.I. (1986) Photoatlas of Inclusions in Gemstones. ABC, Zurich.

Hänni H. A. (1990) A contribution to the distinguishing of sapphire from Kashmir. Journal of Gemmology, Vol. 22, No. 2, pp. 67-75.

Henn U., Bank H. (1990) Rubine aus dem Pamir-Gebirge, USSR. Zeitschrift der Deutschen Gemmologischen Gesellschaft, Vol. 39, No. 4, pp. 201-205.

Hughes R.W. (1997) Ruby \&) Sapphire. RWH Publishing, Boulder, CO.

Hughes R.W., Pardieu V., Soubiraa G., Schorr D. (2006) Moon over the Pamirs: Chasing ruby and spinel in Tajikistan. http://www.ruby-sapphire.com/tajikistan_ruby_and_spinel.htm.

Jacob D.E. (2006) High sensitivity analysis of trace element-poor geological reference glasses by laser-ablation inductively coupled plasma-mass spectrometry (LA-ICP-MS). Geostandards and Geoanalytical Research, Vol. 30, No. 3, pp. 221-235, http://dx.doi.org/10.1111/j.1751-908X.2006.tb01064.x.

Kievlenko E.P. (2003) Geology of Gems. Ocean Pictures Ltd., Littleton, $\mathrm{CO}$.

Konovalenko S.I., Rossovsky L.N. (1980) The first finding of ruby in marbles of Southwestern Pamirs. Zapiski VMO (Proceedings of the All-Union Mineralogical Society), Vol. 109, No. 6, pp. 707-709 (in Russian).

Litvinenko A.K., Barnov N.G. (2010) The history of Pamirs gemstones. Izvestiya Visshikh Uchebnykh Zavedeniy, Geologiya i Razvedka (Proceedings of Higher Educational Institutions, Geology and Prospecting), No. 4, pp. 70-74 [in Russian].

Marfunin A.S. (1974) An Introduction to the Physics of Minerals. Nedra, Moscow [in Russian].

Muhlmeister S., Fritsch E., Shigley J.E., Devouard B., Laurs B.M (1998) Separating natural and synthetic rubies on the basis of trace-element chemistry. Ge)G, Vol. 34, No. 2, pp. 80-101, http://dx.doi.org/10.5741/GEMS.34.2.80.

Nasriddinov Z.Z. (2013) Geological and mineralogical features, determining quality of rough from Snezhnoe deposit. Unpublished Ph.D. thesis, Russian State Geological Prospecting University, Moscow, Russia, 96 pp.

Pham V. L., Hoáng Quang V., Garnier V., Giuliani G., Ohnenstetter D., Lhomme T., Schwarz D., Fallick A., Dubessy J., Phan Trong T. (2004) Gem corundum deposits in Vietnam. Journal of Gemmology, Vol. 29, No. 3, pp. 129-142.

Platonov A.N., Taran M.N., Balitsky V.S. (1984) Nature of Colour of Gems. Nedra, Moscow [in Russian].

Popov V.I. (1936) Minerals of Southern Tajikistan. Pamir, Badakhshan, Darwaz, Karategin. Vol. 28, Leningrad [in Russian].

Rossovsky L.N. (1987) Ruby and sapphire deposits of the AlpineHimalayan fold belt and their formation conditions. In A.V. Klimkin, Ed., Proceedings on Geology and Prospecting of Gemstone Deposits in Tajikistan, Donish Publishers, Dushanbe, Tajikistan, pp. 36-38 [in Russian].

Schaller W.T., Carron M.K., Fleischer M. (1967) Ephesite,

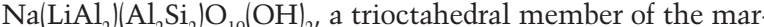
garite group, and related brittle micas. The American Mineral ogist, Vol. 52, Nos. 1-2, pp. 1689-1696.

Schmetzer K., Bank H. (1981) The color of natural corundum. Neues Jahrbuch für Mineralogie Monatshefte, Vol. 1981, No. 2, pp. 59-68.

Smith C.P. (1998) Rubies and pink sapphires from the Pamir Mountain Range in Tajikistan, former USSR. Journal of Gemmology, Vol. 26, No. 2, pp. 103-109.

Sorokina E.S. (2011) Ontogeny and quality of gem ruby from the deposits of Central and South-East Asia. Unpublished Ph.D. thesis, Fedorovsky All-Russian Research Institute of Mineral Resources, Moscow, Russia, 128 pp.

Sorokina E.S., Ozhogina E.G., Jacob D.E., Hofmeister W. (2012) Some features of corundum ontogeny and the quality of ruby from Snezhnoe deposit, Tajikistan (the Eastern Pamirs). Zapiski RMO (Proceedings of the Russian Mineralogical Society), Vol. 141, No. 6, pp. 100-108 [in Russian].

Sorokina E.S., Hofmeister W., Litvinenko A., Häger T., Jacob D. Nasriddinov Z. (2014) Ruby and sapphire from Tajikistan, Central Asia: new geological and mineralogical data. 21st General Meeting of the International Mineralogical Association, Johannesburg, South Africa, September 1-5.

Sutherland F.L., Duroc-Danner J.M., Meffre S. (2008) Age and origin of gem corundum and zircon megacrysts from the Mer caderes-Rio Mayo area, South-West Colombia, South America. Ore Geology Reviews, Vol. 34, pp. 155-168, http://dx.doi.org/10.1016/j.oregeorev.2008.01.004

Taraschan A.N. (1978) Luminescence of Minerals. Naukova Dumka, Kiev [in Russian]. 